\title{
Adult supraglottitis: a life-threatening disease and potential airway emergency
}

\author{
Tom Brennan, Aileen McCabe, Arthur Hennessy
}

Emergency Department, St James's Hospital, Dublin, Ireland

\section{Correspondence to}

Dr Aileen McCabe, aileenmmccabe@gmail.com

Accepted 26 June 2018

\section{DESCRIPTION}

An 87-year-old woman was brought by ambulance to the emergency department (ED) with fever and dyspnoea. There was audible stridor, and the patient was noted to have a large left-sided submandibular swelling. She was in respiratory distress with a respiratory rate of 30 . She was administered $100 \%$ oxygen. The on-call anaesthetics and ear, nose and throat (ENT) team were called emergently on arrival of the patient due to concern regarding possible impending airway compromise. A portable anteroposterior chest X-ray was performed on the patient on arrival to the ED as the cause of her dyspnoea was initially unclear. This showed marked upper airway narrowing (detail from the chest X-ray is depicted in figure 1). Only a venous blood gas was taken from the patient prior to intubation which showed acidosis with a $\mathrm{pH}$ of 7.31 and hypercarbia of 7.62 kilopascals.

Flexible laryngoscopy performed in the ED reported purulent epiglottitis with inflammation of the aryepiglottic folds. The patient was brought to the operating theatre for intubation. Senior anaesthetic doctors performed the nasal intubation with the ENT team also present. Nasal intubation was chosen over the orotracheal route due to diffuse swelling of the floor of the mouth and epiglottis. Propofol and rocuronium were used as induction and paralysing agents, respectively.

CT scan of the neck showed a complex multiloculated left oropharyngeal and hypopharyngeal phlegmon with reactive cervical lymphadenopathy and soft tissue oedema (figure 2). Following a discussion between the ENT team and radiology, a decision was made to proceed with conservative management as there was no drainable collection. Microlaryngocopy was performed in the operating theatre, and swabs were taken from the false cords. A swab from the right false cord grew Streptococcus anginosus. She was extubated on day 10 and received a total of 23 days of intravenous ceftriaxone, clindamycin and metronidazole. The

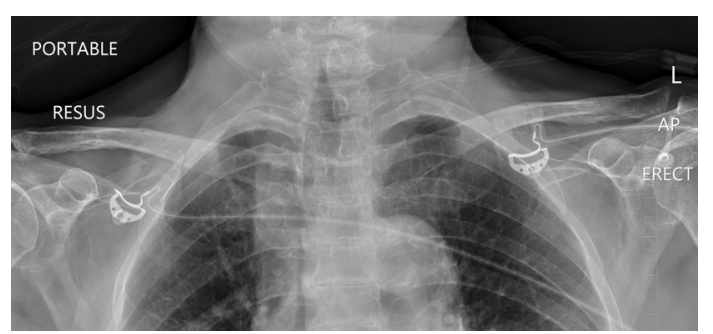

Figure 1 Anteriorposterior radiograph showing marked narrowing of the upper airway.

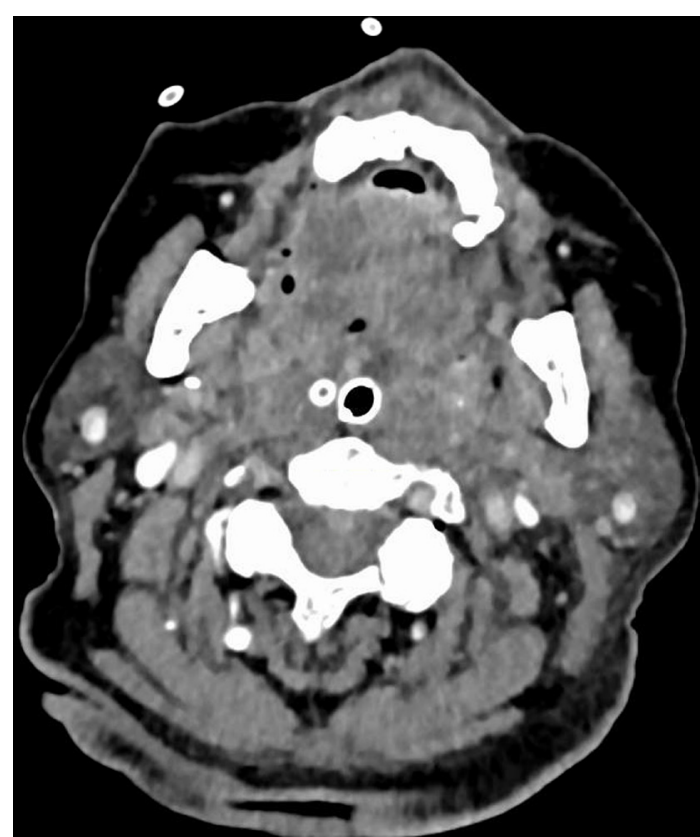

Figure 2 CT scan of the neck showed a complex multiloculated left oropharyngeal and hypopharyngeal phlegmon with reactive cervical lymphadenopathy and soft tissue oedema.

patient was also administered a 10-day course of intravenous dexamethasone. The patient made a good recovery.

Adult supraglottitis is a serious, life-threatening disease because of its potential for complete upper airway obstruction. ${ }^{1}$ It is characterised by inflammation of the supraglottic structures of the larynx: the arytenoids, the false vocal cords, the laryngeal ventricles, the aryepiglottic folds and the epiglottis. ${ }^{1}$ Adults with supraglottitis typically present with odynophagia, cervical lymphadenopathy, sore throat, dysphagia, fever and respiratory distress. ${ }^{12}$ Diagnosis of supraglottitis is made by flexible nasolaryngoscopy revealing an erythematous and swollen supraglottitis. ${ }^{1}$ CT may have a role to look for sequalae of supraglottitis such as a parapharyngeal abscess. ${ }^{1}$ The signs of deep neck infection seen on the CT in this case are consistent with complications of supraglottitis seen in other case series. ${ }^{34}$ Airway management by senior anaesthetists/ENT surgeons is critical as endotracheal intubation or tracheostomy may be indicated.

The demographics of supraglottitis have changed. Haemophilus influenza type B (Hib) was the most common organism responsible but group A beta haemolytic Streptococci has now overtaken it due to widespread Hib vaccination. ${ }^{2}$ The incidence of 
adult supraglottitis has stayed constant at 1 to 4 per 100000 people per year. ${ }^{2}$ A third-generation cephalosporin is usually given until an exact microbiological diagnosis is made. The use of corticosteroids has been associated with shorter intensive care unit and overall lengths of stay. ${ }^{2}$

The X-ray in our case demonstrates the marked upper airway narrowing (figure 1). Classically, a lateral neck soft tissue radiograph shows characteristic signs of thickening of the epiglottis (thumb sign). A lateral neck soft tissue X-ray was not obtained in our case due to prioritisation of airway management. Indeed, it should be noted that obtaining plain film radiography does not improve diagnosis and should not be prioritised in a patient with

\section{Learning points}

- A high index of clinical suspicion must be maintained to ensure that supraglottitis, a life-threatening condition, is not missed in the emergency department.

- Urgent airway management by senior anaesthetists/ear, nose and throat surgeons in cases of potential airway emergency.

- Diagnosis is confirmed at flexible nasolaryngoscopy. a compromised airway. The portable chest X-ray was performed in our patient to rule out other causes of dyspnoea such as pneumothorax and lower respiratory tract infection when the diagnosis was unclear on the initial assessment.

Contributors TB was involved in drafting the manuscript. AMcC participated in drafting, revising and conception of the manuscript. AH participated in revising the manuscript.

Funding There was no specific grant for this research from any funding agency in the public, commercial or not-for-profit sectors.

Competing interests None declared.

Patient consent Obtained.

Provenance and peer review Not commissioned; externally peer reviewed.

\section{REFERENCES}

1 Navaratnam AV, Smith ME, Majeed A, et al. Adult supraglottitis: a potential airway emergency that can present in primary care. Br J Gen Pract 2015;65:99-100.

2 Guardiani E, Bliss M, Harley E. Supraglottitis in the era following widespread immunization against Haemophilus influenzae type B: evolving principles in diagnosis and management. Laryngoscope 2010;120:2183-8.

3 Smith MM, Mukherii SK, Thompson JE, et al. CT in adult supraglottitis. AJNR Am J Neuroradiol 1996;17:1355-8.

4 Bizaki AJ, Numminen J, Vasama JP, et al. Acute supraglottitis in adults in Finland: review and analysis of 308 cases. Laryngoscope 2011;121:2107-13.

Copyright 2018 BMJ Publishing Group. All rights reserved. For permission to reuse any of this content visit

http://group.bmj.com/group/rights-licensing/permissions.

BMJ Case Report Fellows may re-use this article for personal use and teaching without any further permission.

Become a Fellow of BMJ Case Reports today and you can:

- Submit as many cases as you like

- Enjoy fast sympathetic peer review and rapid publication of accepted articles

- Access all the published articles

- Re-use any of the published material for personal use and teaching without further permission

For information on Institutional Fellowships contact consortiasales@bmjgroup.com

Visit casereports.bmj.com for more articles like this and to become a Fellow 